\title{
KAJIAN YURIDIS TERHADAP AGEN \\ PERJALANAN ( TRAVEL AGENT) \\ DALAM BISNIS PARIWISATA
}

\author{
Hasyim Sofyan Lahilote
}

\begin{abstract}
Abstrak
Krisis multidimensional yang melanda Indonesia tahun 1998 telah menggairahkan kembali bisnis perjalanan wisata di Indonesia. Dengan rendahnya nilai mata uang rupiah menjadi keuntungan tersendiri bagi Indonesia sehingga banyak turis asing yang ber- kunjung ke Indonesia. Hal ini ditandai dengan banyaknya pen- dirian usaha-usaha agen perjalanan (Travel Agent) di tanah air. Keberadaan agen perjalanan pada prinsipnya sama dengan badan usaha lainnya dari segi yuridis formal. Sedangkan jenis badan hukum dari usaha tersebut berbentuk Perseroan Terbatas (PT), koperasi, firma, CV.
\end{abstract}

Kata Kunci: Travel Agent, Pariwisata, badan hukum

\section{Latar Belakang}

Sejak timbulnya krisis multidimensional yang melanda tanah air pada sekitar tahun 1998, timbul berbagai masalah yang dihadapi oleh bangsa Indonesia dalam upaya untuk keluar dari aneka kemelut yang melanda, yang di dalamnya terasa sekali penderitaan yang bukan saja dialami oleh pemerintah Indonesia saja, melainkan juga dirasakan oleh berbagai lapisan masyarakat, para profesional, tenaga kerja baik di sektor formal maupun informal, para pelaku usaha baik usaha di sektor barang ataupun di sektor jasa, serta berbagai kalangan yang berkecimpung di bidang ekonomi, politik, hukum, sosial kemasyara- katan, dan lain-lain.

Hal ini timbul karena begitu banyaknya serta begitu kompleksnya permasalahan yang ada sehingga proses penyelesaiannya membutuhkan berbagai faktor yang pada akhirnya memerlukan waktu yang panjang 
untuk menyelesaikan secara lengkap dan menyeluruh permasalahan yang ada.

Dalam bisnis perjalanan, dengan timbulnya krisis tersebut sedikit mempengaruhi kelangsungan usaha tersebut dengan melihat pada dua faktor utama antara lain:

- Jika kita melihat latar belakang orang-orang yang melakukan perjalanan tersebut, maka kita dapat menyimpulkan bahwa adanya krisis ekonomi ini akan mengakibatkan bisnis agen perjalanan akan mengalami penurunan intensitas kerja. Hal ini dimungkinkan mengingat adanya krisis ekonomi yang diawali dengan krisis mo- neter pada tahun 1997 yang membuat nilai mata uang rupiah kita merosot tajam pada titik terendah ini, mengakibatkan daya beli masyarakat terhadap produk-produk perjalanan yang dita- warkan oleh para pengelola jasa perjalanan menjadi lemah se- hingga berimbas pada penurunan produktivitas usaha sektor jasa perjalanan.

- Jika kita melihat pada latar belakang bahwa mereka yang melakukan kegiatan perjalanan tersebut adalah orang-orang yang berasal dari luar negeri ( orang asing ) kita dapat menyimpulkan bahwa kegiatan usaha perjalanan tersebut akan mengalami kenaikan intensitas kerja mengingat para wisatawan asing tersebut banyak membawa devisa dari luar yang pada prinsipnya jika dibandingkan dengan nilai mata uang rupiah kita tentunya mempunyai nilai yang sangat tinggi sehingga memungkinkan suatu biro penyedia jasa perjalanan tersebut, dapat meningkatkan produktivitas mereka disebabkan banyaknya keuntungan yang diperoleh dari perbedaan nilai mata uang tersebut.

Dengan berbagai keuntungan dari sisi pendapatan yang didapat pada sektor perjalanan ini, kemudian bermunculanlah berbagai macam bentuk badan usaha yang berbentuk biro perjalanan (travel agent) untuk menyikapi perkembangan arus perhubungan di tanah air. Hal ini berpengaruh sangat besar terhadap pendapatan daerah-daerah yang tingkat mobilitas masyarakatnya sangat tinggi terutama daerah-daerah yang banyak sekali tersimpan obyek-obyek pariwisata serta daerahdaerah yang menjadi tempat para pengusaha menanamkan 
investasi atau menjalankan bisnisnya secara langsung.

Agen perjalanan pada prinsipnya berkedudukan sama dengan badan usaha lainnya dari segi yuridis formal. Hal ini bisa dilihat dalam pasal 3 Keputusan menteri Pariwisata, Pos dan Telekomunikasi No. KM.10/PW.102/MPPT-93 tentang ketentuan usaha biro perjalanan wisata dan agen perjalanan wisata. Menurut pasal tersebut, bentukbentuk badan usaha dari agen perjalanan dapat berupa Perseroan Terbatas, Koperasi, Firma, atau Perseroan Komanditer. Di samping itu menurut pasal 4 dari pasal tersebut juga menegaskan bahwa bidang usaha dari biro perjalanan umum terbuka untuk penanaman modal asing (PMA) dan penanaman modal dalam negeri (PMDN).

Sebagai suatu bentuk badan usaha yang didirikan dan melakukan kegiatan usaha diatas wilayah negara Republik Indonesia sudah barang tentu agen perjalanan harus tunduk dan patuh kepada peraturan perundang-undangan yang berlaku baik dari segi syarat-syarat berdirinya badan usaha tersebut maupun dari segi kontribusi yang diberikan kepada negara dalam rangka pembangunan ekonomi khususnya di wilayah tempatnya melakukan kegiatan usaha.

Dari segi kontribusi yang diberikan kepada negara, kita dapat melihat seberapa besar potensi yag bisa digali oleh negara dengan adanya bisnis jasa perjalanan ini dengan melihat beberapa pendekatan yang mungkin bisa ditarik dari bisnis ini dari segi-segi antara lain:

- Segi perpajakan

Dengan adanya bisnis usaha perjalanan ini, pemerintah dapat me- narik pajak dari margin keuntungan yang diperoleh dari pelaku-pelaku usaha agen perjalanan setiap tahun sesuai dengan peraturan perundang-undangan yang berlaku.

- Segi pemasukan devisa

Dengan adanya bisnis usaha perjalanan ini, pemerintah diuntung- kan dengan masuknya devisa dari luar yang dibawa oleh para turis asing ke dalam wilayah republik Indonesia yang memungkinkan bertambahnya cadangan devisa negara.

- Segi tenaga kerja

Dengan adanya bisnis usaha perjalanan ini, akan banyak tenaga 
kerja di sektor informal yang terserap sehingga dengan demikian pemerintah telah dibantu oleh para pelaku usaha di sektor usaha perjalanan ini, dengan menimbulkan berbagai lapangan kerja baru. Bisnis ini secara ekonomis akan merangsang timbulnya potensi usaha dibidang jasa perhotelan, jasa pariwisata, jasa makanan (restoran), serta berbagai elemen lain yang terkait baik secara langsung maupun tidak langsung dengan keberadaan bisnis ini.

\section{Pembahasan}

\section{A. Pengertian Agen Perjalanan}

Agen perjalanan adalah terjemahan dari suatu istilah dalam bahasa Inggris yaitu travel agency yang berarti suatu perusahaan keagenan yang kegiatannya menitik beratkan pada bisnis perjalanan. Ada beberapa istilah yang dipakai dan dikenal dalam dunia pariwisata terhadap isti- lah agen perjalanan ini antara lain Travel Services, Travel Bureau, Tour Operator, Tourist Bureau, atau tour and travel services. Semua istilah tersebut bermuara pada satu pengertian yaitu perusahaan yang me- lakukan kegiatan memberikan informasi dan pelayanan bagi orang yang akan melakukan perjalanan pada umumnya dan perjalanan wi- sata khususnya.

Berbicara tentang agen perjalanan terlebih dahulu kita harus melihat aspek-aspek apa saja yang terkaitkan dengan keberadaan agen perjalanan ini. Dengan melihat keadaan nyata dalam bisnis per- dagangan jasa, kita dapat menyimpulkan kurang lebih ada dua hal/ aspek yang terkandung di dalam agen perjalanan, yaitu aspek peng- angkutan niaga dan aspek pariwisata.

Dari sudut pandang aspek pengangkutan niaga, menurut Lestari Ningrum Agen perjalanan adalah pihak yang mencarikan penumpang bagi pengangkut yang bertindak atas nama pengangkut dan menyediakan fasilitas angkutan kepada penumpang dengan cara menjual tiket/karcis kepada penumpang dan pihak agen perjalanan mendapatkan provisi dari pihak pengangkut. Adapun hubungan

Lestari Ningrum, Usaha Perjalanan Wisata dalam Perspektif Hukum Bisnis, Citra Aditya Bakti, Bandung, 2004. 
hukum yang terjadi antara agen perjalanan dan pihak pengangkut adalah pemberian kuasa keagenan (contract of representatif agency). Hal lain yang terkait dengan agen perjalanan dalam hubungannya dengan aspek pengangkutan niaga antara lain: Pengangkut, Pengirim (consigner), Penumpang (Passanger), ekspeditur, perusahaan muat bongkar (stevedoring), perusahaan pergudangan (warehousing), dan penerima (consignee).

Sedangkan berbicara tentang agen perjalanan dalam kaitannya dengan aspek pariwisata, masih banyak istilah yang digunakan dan dikenal oleh berbagai kalangan mengenai agen perjalanan ini. Hingga saat ini banyak istilah yang dikeluarkan sebagai pengganti istilah agen perjalanan. Istilah lain yang digunakan sebagai pengganti kata agen perjalanan antara lain: Travel services, tour operator, travel bureau, tourist bureau, atau tours and travel services.

Istilah-istilah tersebut sepintas memang kelihatan sama, akan tetapi kalau kita teliti lebih jauh ada beberapa istilah yang sebenarnya mempunyai arti yang lebih luas dari istilah-istilah lainnya yang ber- kaitan.

Misalnya istilah tour operator atau dalam kata lain tour and travel services menunjuk pada kegiatan usaha d imana kegiatan perjalanan itu antara lain menyelenggarakan kegiatan:

- Merencanakan dan menyelenggarakan macam-macam perjalanan wisata.

- Merencanakan dan menjual paket wisata.

- menyediakan tenaga pramuwisata, tour leader, dan lain-lain.

- Menyewakan angkutan wisata, menyediakan atau memberikan fa- silitas angkutan borongan, dan lain-lain.

Obyek cakupan dari kegiatan yang diselenggarakan oleh tour operator/tour and travel services kelihatannya lebih luas jika kita bandingkan dengan kegiatan yang dilakukan oleh travel agent yang antara lain menitikberatkan pada penjualan produk-produk pariwisata yang ditawarkan oleh perusahaan tour operator, serta penjualan tiket sarana pengangkutan, melakukan pemesanan (reservation) kamar hotel,

Oka A. Yoeti, Pengantar Ilmu Pariwisata, Angkasa, Bandung, 1996. 
pertunjukan, serta mengurus dokumen perjalanan, dan lain-lain.

Menurut keputusan menteri pariwisata, pos, dan telekomuniksai Nomor KM.10/PW.102/MPPT-93, hanya dikenal istilah biro perjalanan wisata dan agen perjalanan wisata, di mana biro perjalanan wisata adalah usaha yang merencanakan perjalanan wisata dan atau jasa pelayanan penyelenggaran wisata (pasal 1 ayat 1), dan agen per- jalanan wisata adalah usaha jasa perantara untuk menjual atau meng- urus jasa untuk perjalanan wisata (pasal 1 ayat 3).

Adapun lingkup kegiatan dan penguasaan dari biro perjalanan wisata dan agen perjalanan wisata meliputi:

- Penyusunan dan penyelenggaraan paket wisata

- Penyediaan dan/atau pelayanan angkutan wisata

- Pemesanan akomodasi, restoran, dan sarana lainnya

- Penyelenggaraan pelayanan perlengkapan (dokumen) perjalanan wisata (Pasal 2 ayat 1 )

Selanjutnya, walaupun antara biro perjalanan wisata dengan agen perjalanan wisata terdapat lingkup kegiatan yang sama (pasal 2 ayat 1), akan tetapi kedudukan hukum dari masing-masing perusahaan tersebut tidaklah sama bahkan berbeda satu sama lain, di mana di satu pihak kegiatan biro perjalananan wisata antara lain adalah yang merencanakan serta menyusun suatu program paket wisata yang kemudian secara langsung bisa menjualnya kepada para wisatawan, atau kepada para agen penjualan dalam hal ini para agen perjalanan wisata, sementara dipihak yang lain peran agen perjalanan wisata hanyalah menjual produk-produk wisata yang ditawarkan oleh biro perjalanan wisata dengan tidak boleh mengubah atau mengganti isi dari produk-produk yang ditawarkan kepada para wisatawan.

Dengan demikian antara biro perjalanan wisata dan agen perjalanan wisata terlebih dahulu harus ada semacam kerja sama bisnis secara kontraktual yang dibuat dan ditanda tangani oleh kedua belah pihak dalam rangka penjualan produk-produk pariwisata. Kerja sama terse- but dapat dituangkan dalam berbagai bentuk kerja sama bisnis yang di- kenal dalam dunia usaha perjalanan wisata, antara lain kontrak lisensi, kontrak franchise, dan kontrak agensi. Dari berbagai bentuk kontrak 
tersebut, yang paling banyak dipakai khususnya untuk kegiatan usaha perjalanan wisata adalah kontrak agensi.

Adapun jenis perusahaan agen perjalanan wisata menurut pasal 3 Keputusan menteri Pariwisata, Pos dan Telekomunikasi No. KM.10/ PW.102/MPPT-93 tentang ketentuan usaha biro perjalanan wisata dan agen perjalanan wisata, adalah dapat berupa Perseroan Terbatas (PT), Koperasi, Firma, atau CV.

\section{B. Sejarah Timbulnya Agen Perjalanan}

Keadaan manusia pada saat dia diciptakan telah mempunyai tangan dan kaki yang bertujuan untuk melakukan kegiatan yang dapat melangsungkan kehidupanya kelak didunia. Dengan adanya ben- tuk tubuh yang demikian memungkinkan setiap manusia untuk ber- gerak ke mana saja yang dikehendakinya dan mencari apa saja yang diingininya demi mempertahankan serta melangsungkan kehidupan termasuk mengembara ke setiap tempat untuk memenuhi kebutuhan hidup.

Terdorong oleh rasa lapar serta haus, rasa ingin tahu akan sesuatu, rasa takut, rasa untuk mencari kekuasaan, serta berbagai perasaan lain, manusia mulai memikirkan untuk melakukan kegiatan yang melatarbelakangi manusia mengadakan perjalanan.

Perjalanan berkembang karena adanya kebutuhan untuk tetap bertahan, keinginan untuk memperluas jaringan perdagangan, dan keinginan untuk menaklukkan atau memperluas daerah jajahan. Jauh sebelum manusia dapat melakukan perjalanan lewat jalan raya, ber- layar dengan kapal, atau terbang dengan pesawat udara, satu-satunya metode transportsi yang dapat mereka pergunakan adalah kaki me- reka sendiri. Manusia-manusia pertama adalah nomadic, dipaksa un- tuk berjalan karena kebutuhan mereka untuk berburu rusa, bison, burung, dan binatang buruan lainnya.

Dalam perkembangannya, metode transportasi yang digunakan oleh manusia mengalami kemajuan dengan menggunakan binatang

sebagai alat transportasi di samping penemuan dan pemakaian roda-

Dennis L. Foster, An introduction to Travel \& Tourism, edisi bahasa Indonesia,

PT RajaGrafindo Persada, Jakarta, 2000. 
roda yang dapat ditarik oleh binatang untuk membawa barangbarang dagangannya dari satu tempat ke tempat lain.

Penemuan uang sebagai alat pembayaran oleh bangsa sumeria di Babylonia dan majunya perkembangan perdagangan yang dimulai kira-kira tahun 4000 SM merupakan titik tolak tanda dimulainya perjalanan untuk tujuan perdagangan waktu itu.

Selanjutnya dari usaha-asaha perdagangan yang dilakukan oleh manusia dan dengan dimudahkannya sistim transportasi dengan penemuan alat-alat transportasi yang baru yang dapat membantu manusia melakukan ekspansi dagangnya ke daerah lain diluar tempat tinggalnya mendorong manusia untuk melakukan perluasan daerahdaerah baru yang menurutnya dapat memperkuat kemampuannya untuk mencukupi kebutuhan hidupnya sehingga mendorongnya melakukan perjalanan ke daerah lain dengan tujuan yang tidak lagi sama dengan tujuan semula yakni untuk melakukan perdagangan, akan tetapi melakukan perluasan daerah kekuasaan dari segi politik dengan memaksa daerah-daerah lain mengikuti kemauannya dalam arti kata melakukan penjajahan terhadap daerah yang ditaklukkan. Fakta ini dapat dilihat dalam berbagai lembaran sejarah penaklukan yang dilakukan oleh bangsa yang tingkat pertahanan dan alat transportasinya lebih kuat terhadap beberapa bangsa yang tingkat pertahanan dan alat transportasinya lebih lemah.

Dalam perkembangan kontemporer, hasrat melakukan perjalanan banyak diilhami oleh keinginan manusia untuk mengetahui sesuatu, yang mendorongnya untuk mencoba mengetahui lebih banyak keberadaan dari daerah-daerah yang ada di sekitar lingkungannya dengan melakukan petualangan-petualangan ke berbagai daerah yang sebelumnya belum pernah dilihatnya. Marco Polo telah membuktikan hal itu dengan melakukan petualangan dengan menjelajahi jalan raya dari benua Eropa ke Tiongkok dan kemudian kembali ke Venesia. Keingintahuan manusia terhadap berbagai bentuk dan ragam budaya yang ada di suatu daerah tertentu telah menciptakan suatu bentuk citra yang baru dalam dunia perjalanan, yaitu pariwisata.

Op. cit.

Ibid. 
Kegiatan pariwisata ini pada awalnya adalah hak khusus yang dinikmati secara ekslusif oleh orang-orang kaya saja. Di Yunani, resor-resor untuk bersantai dibangun dibangun dibagian luar kotakota yang penguh sesak atau sepanjang garis pantai, untuk memungkinkan mereka yang berasal dari kelas lebih tinggi lari dari tekanan khidupan kota, yang kemudian tumbuh dan berkembang di benua Eropa secara keseluruhan pada akhir abad ke-18, dan kemudian menyebar ke seluruh dunia hingga sekarang ini. Hampir tak dapat dikatakan di manapun daerah di dunia ini yang mempunyai tempat-tempat menarik serta kebudayaan yang unik yang tidak tersentuh dengan aspek pariwisata.

Setelah mengalami berbagai pergeseran nilai dari maksud / tujuan yang ingin dicapai dari orang-orang yang melakukan kegiatan per- jalanan dari yang semula bertujuan untuk mencukupi kebutuhan hi- dupnya dengan berdagang kemudian beralih tujuan kepada perluasan daerah-daerah kekuasaan politik, kemudian menjelma kepada tujuan-tujuan yang sifatnya mencari kesenangan semata atau mencari tempat-tempat yang sifatnya unik dengan berbagai bentuk petualangan atau kegiatan perjalanan.

Seiring dengan adanya industrialisasi di berbagai bidang termasuk di bidang transportasi, di mana banyak sekali alat transportasi yang telah mengalami berbagai macam kesempurnaan dari segi teknologi, seperti telah ditemukannya pesawat terbang sebagai sarana transportasi udara oleh Wright bersaudara di mana perkembangannya sampai sekarang telah mengalami bermacam kesempurnaan dan dimodernisasikannya sistim perjalanan dengan kereta Api yang lebih cepat dan efisien oleh berbagai negara maju di dunia, sampai pada penciptaan kapal-kapal laut mewah yang dapat membawa ribuan orang dalam pelayaran dan dapat menempuh jarak yang jauh dalam waktu singkat, telah mendorong sebagian manusia untuk membuka usaha/bisnis yang sifatnya baru dalam dunia perdagangan di bidang jasa dalam rangka mengantisipasi keberadaan bisnis transportasi yang telah berkembang dengan cepat.

Menurut Dennis L. Foster, bisnis penyediaan jasa perjalanan per-

Op. cit. 
tama kali diperkenalkan oleh Thomas Cook seorang berkebangsaan Inggris dengan membuka biro perjalanan eceran pertama pada ta- hun 1845. Dalam kegiatan bisnisnya beliau membujuk sejumlah perusahaan kereta api dan kapal uap untuk membayar sejumlah komisi kepadanya karena ia menjual sejumlah tiket dari beberapa kapal uap dan kereta api dari perusahaan tersebut. Sistem kerjanya ialah dengan mengorganisasi kelompok-kelompok dan mengatur perjalanan dengan kereta api dan menyediakan hiburan maupun makanan dalam perjalananan sejak 1841, dan bermaksud memperluas bisnisnya ke seluruh Inggris, Skotlandia, dan daratan Eropa.

Dari sistem yang semula sederhana ini kemudian berkembang sam- pai pada memberikan perlakuan-perlakuan khusus kepada berbagai penumpang dengan menyertakan pemandu-pemandu wisata pada setiap kali mengadakan perjalanan yang menjelaskan berbagai macam obyek wisata yang dikunjungi oleh para wisatawanan, telah membuka berbagai lapangan kerja yang berhubungan dengan kegiatan ini dan telah mendorong peningkatan produktivitas kerja berbagai usaha transportasi di seluruh wilayah dunia yang banyak menyimpan obyek-obyek pariwisata terutama tempat-tempat obyek pariwisata yang banyak dikunjungi orang dan aneka ragam budaya yang unik dan menarik bagi para wisatawan.

\section{Kontrak Agensi}

Kontrak agensi menurut Lestari Ningrum merupakan perjanjian bis- nis yang terjadi antara agen dan pemilik suatu produk, di mana agen menawarkan produk milik suatu perusahaan kepada para calon pem- beli, dengan mendapatkan "komisi agen" yang biasanya merupakan presentasi tertentu dari harga penjualan.

Patut digarisbawahi dalam kontrak ini bahwa pihak agen dalam kegiatannya tidak menanda tangani suatu perjanjian jual beli dengan para konsumen/pembeli produk, akan tetapi perjanjian jual beli terse- but berlangsung antara pemilik produk dan pembeli.

Sedangkan keuntungan yang didapat dari para agen perjalanan ini

\footnotetext{
Op-cit.
} 
biasanya hanyalah dalam bentuk komisi yang didapat dari persentasi tertentu dari harga penjualan, di samping itu pertanggungjawaban atas adanya klaim kerugian atas pelayanan jasa perjalanan langsung berada pada pemilik produk yang menjual/memproduksi langsung paket perjalanan tersebut.

Selanjutnya sebagai salah satu bentuk perjanjian, agar bisa dikatakan bahwa perjanjian itu sah, maka jenis kontrak agensi ini harus tunduk dan sesuai dengan apa yang termuat dalam pasal 1320 KUH Perdata, yang mengatakan bahwa untuk sahnya suatu perjanjian diperlukan empat syarat:

1. Kesepakatan mereka yang mengikatkan dirinya.

2. Kecakapan untuk membuat suatu perjanjian.

3. Mengenai suatu hal tertentu.

4. Suatu sebab yang tidak terlarang.

Keempat syarat tersebut dapat dibagi dalam dua bagian di mana syarat pada poin 1 dan 2 adalah syarat yang menyangkut subyek (orang) dari perjanjian tersebut, sehingga tidak terpenuhinya syarat subyektif tersebut dapat membuat perjanjian tersebut dibatalkan (voidable). Sementara syarat pada poin 3 dan 4 menyangkut obyek (prestasi) dari perjanjian tersebut sehingga tidak terpenuhinya syarat tersebut akan membuat perjanjian batal demi hukum (null and void).

Selanjutnya menurut Oka A. Yoeti, di Indonesia kegiatan kepariwisataan yang pada prinsipnya merupakan cikal bakal timbulnya berbagai bisnis jasa biro perjalanan dimulai sejak 1910 setelah dikeluarkannya keputusan gubernur jenderal Hindia Belanda atas pembuatan Vereeneging Teoristen Verkeer (VTV) yang merupakan badan atau official tourist bureau pada masa itu di Hindia Belanda.

Yang menarik dari keberadaan Vereeneging Teoristen Verkeer (VTV) ini adalah kedudukannya selain sebagai badan hukum publik yang diciptakan oleh pemerintah kolonial Belanda di Indonesia untuk mengatur masalah kepariwisataan, juga berfungsi sebagai tour operator atau travel agent yang melaksanakan kegiatan bisnis dengan

Ricardo Simanjuntak, "Teknik Perancangan Kontrak Bisnis", Kontan, Mingguan

Ekonomi dan Bisnis, 2003. 
mendapatkan keuntungan-keuntungan dari komisi-komisi yang di- peroleh dari hotel-hotel atau perusahaan-perusahan angkutan yang menyelenggarakan kegiatan kepariwisataan. Dengan demikian dapat disimpulkan adanya dualisme fungsi dari keberadaan VTV ini dari yang berfungsi sebagai badan negara yang sifatnya publik, juga ber- fungsi sebagai tour operator atau travel agent yang berfumgsi sebagai badan hukum privat.

Kegiatan kepariwisataan, sekalipun multi aspek, bukanlah kegiatan yang tidak dapat didefinisikan. Menurut Ida Bagus Wyasa Putra, bisnis pariwisata adalah aspek kegiatan kepariwisataan yang berorientasi pada penyediaan jasa pariwisata. Bisnis ini meliputi seluruh kegiatan penyediaan jasa jasa (services) yang dibutuhkan wisatawan. Kegiatan ini meliputi jasa perjalanan (travel) dan transportasi (transportation), penginapan (accomodation), jasa boga (restaurant), rekreasi (recreation), dan jasa-jasa lain yang terkait, seperti jasa informasi, telekomunikasi, penyediaan tempat dan fasilitas untuk kegiatan tertentu, penukaran uang (money changer), dan jasa hiburan (entertainment).

Selanjutnya setelah Indonesia merdeka, dan seiring dengan kemauan dari pemerintah Indonesia untuk menciptakan sumber-sumber pendapatan baru bagi negara dalam rangka menggalakan pembangunan di berbagai bidang antara lain di bidang pariwisata, pemerintah telah mengeluarkan berbagai produk peraturan perundangundangan yang berhubungan dengan kegiatan agen perjalanan ini antara lain Undang-Undang No. 15 tahun 1992 tentang penerbangan, Undang-Undang No. 14 tahun 1992 tentang lalu lintas dan angkutan jalan, Undang-Undang No. 13 tahun 1992 tentang perkeretaapian, Undang-Undang No. 21 tahun 1992 tentang pelayaran, UndangUndang No. 9 tahun 1990 tentang kepariwisataan, keputusan menteri pariwisata, pos, dan telekomunikasi No. KM.10/PW.102/MPPT-93 tentang ketentuan usaha biro perjalanan wisata dan agen perjalanan wisata, keputusan menteri perindustrian dan perdagangan No. 408/ $\mathrm{MPP} / \mathrm{KEP} / 10 / 1997$ tentang ketentuan dan tata cara pemberian tanda daftar usaha perdagangan (TDUP) dan surat izin usaha perdagangan

Ida Bagus Wyasa Putra, Hukum Bisnis Pariwisata, PT. Refika Aditama, Bandung, 2003. 
(SIUP) dan lain-lain.

\section{Kesimpulan}

Berdasarkan uraian di atas, dapat diambil kesimpulan sebagai ber- ikut:

1. Agen perjalanan (Travel Agent) pada prinsipnya berkedudukan sama dengan badan usaha lainnya dari segi yuridis formal.

2. Adapun jenis perusahaan agen perjalanan menurut keputusan menteri Pariwisata, Pos dan Telekomunikasi No. KM.10/PW.102/ MPPT-93 tentang ketentuan usaha biro perjalanan wisata dan agen perjalanan wisata, adalah dapat berupa Perseroan Terbatas (PT), Koperasi, Firma, atau CV.

3. Ketentuan hukum terhadap kontrak agensi yang berlaku antara biro perjalanan wisata dengan agen perjalanan wisata pada prinsipnya tunduk pada pasal 1320 KUHPerdata. 


\section{DAFTAR PUSTAKA}

Foster Dennis L., An Introduction to Travel \& Tourism, edisi Bahasa Indo- nesia, (Jakarta: PT. RajaGrafindo Persada, 2000).

Ningrum Lestari, SH, 2004, Usaha Perjalanan Wisata dalam Perspektif Hukum Bisnis, (Bandung: PT. Citra Aditya Bakti, 2004)

Putra Ida Bagus Wyasa, SH, MH, Hukum Bisnis Priwisata, (Bandung: PT. Refika Aditama, 2003).

Simanjuntak Ricardo, 2003, "Teknik Perancangan Kontrak Bisnis (Bisnis Contract Drafting)", Kontan, Mingguan Ekonomi dan Bisnis.

Yoeti Oka A. H. Drs, MBA, Pengantar Ilmu Pariwisata, (Bandung: Ang- kasa, 1996).

Keputusan Menteri Pariwisata, Pos dan Telekomunikasi N. KM.10/ PW.102/MPPT-93 tentang ketentuan usaha biro perjalanan wisata dan agen perjalanan wisata

Kitab Undang-Undang Hukum Perdata 